\title{
Disseminated granuloma annulare and hepatocellular carcinoma: association or coincidence?
}

\author{
Tiago Mestre, Ana Maria Rodrigues, Jorge Cardoso
}

Hospital Curry Cabral, Centro Hospitalar Lisboa Central, Lisbon, Portugal

\section{Correspondence to}

Dr Tiago Mestre,

tiago.g.mestre@gmail.com

Accepted 15 October 2014

\section{DESCRIPTION}

Granuloma annulare is a granulomatous skin disease of unknown aetiology. It is more common in women and has a disseminated form in $10-15 \%$ of patients. A small portion of these patients have an associated disease such as diabetes mellitus, viral infection, vaccine reaction or cancer. Haematological neoplasms and adenocarcinomas are those most frequently found. ${ }^{1}$

The authors present the case of 68-year-old man with a recent diagnosis of hepatocellular carcinoma (figure 1). Simultaneously with the diagnosis, he referred to the appearance of more than 10 infiltrated erythematous plaques, smooth surfaced and annular shaped (figure 2). Cutaneous histopathological examination of these lesions showed a lymphohistiocytic infiltrate with multinucleated giant cells in a palisade pattern in the papillary and reticular dermis and some foci of granulomatous reaction surrounding foci of altered collagen. This was compatible with the diagnosis of granuloma annulare (figure 3). The patient was treated with topical dipropionate of $\beta$ methasone twice daily with a slight improvement of the dermatosis. Palliative treatment with chemoembolisation was offered to the patient, but he died some months later.

The pathogenesis of granuloma annulare is unknown. In the cases linked to cancer there is evidence suggesting that the mechanism of pathogenesis is related to a type $1 \mathrm{~T}$ helper (Th-1 type) delayed hypersensitivity cross-reaction, in which the tumour antigens act as triggers of the dermatosis. $^{2}$ The temporal relationship between the

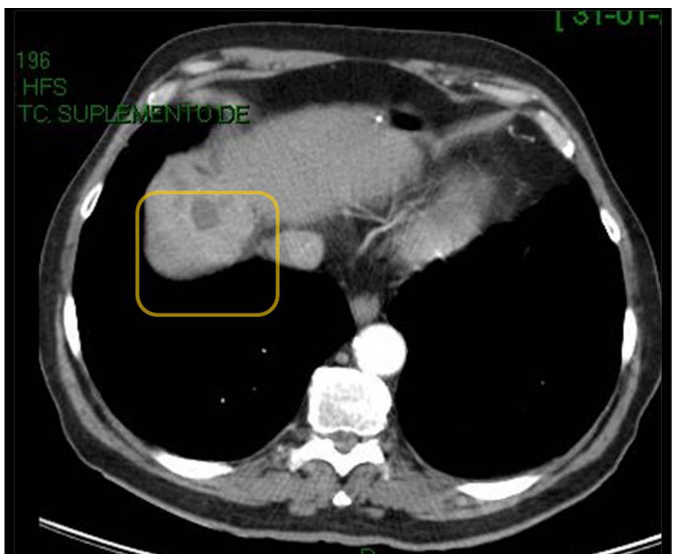

Rodrigues AM, Cardoso J. BMJ Case Rep Published online: [please include Day Month Year] doi:10.1136/ bcr-2014-205883
Figure 1 CT scan: nodule $(3.5 \mathrm{~cm})$ in segment VIII with portal thrombus adjacent, highly suggestive of hepatocellular carcinoma, $\alpha$-fetoprotein was $38 \mathrm{ng} / \mathrm{mL}$ (ref: $0-7 \mathrm{ng} / \mathrm{mL}$ ).

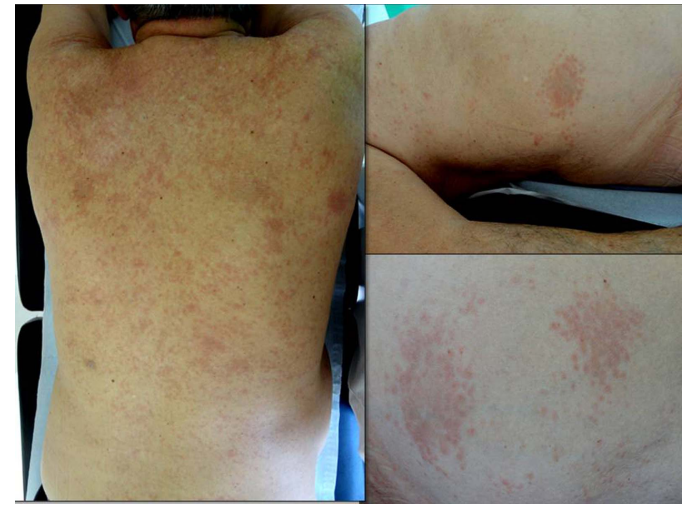

Figure 2 Erythematous papules forming annular infiltrated plaques on the trunk and limbs.

diagnosis of the neoplasia and granuloma annulare is variable; it may appear before, during or after the first diagnosis (18 months to 7 years). Haematological neoplasms are the most frequently

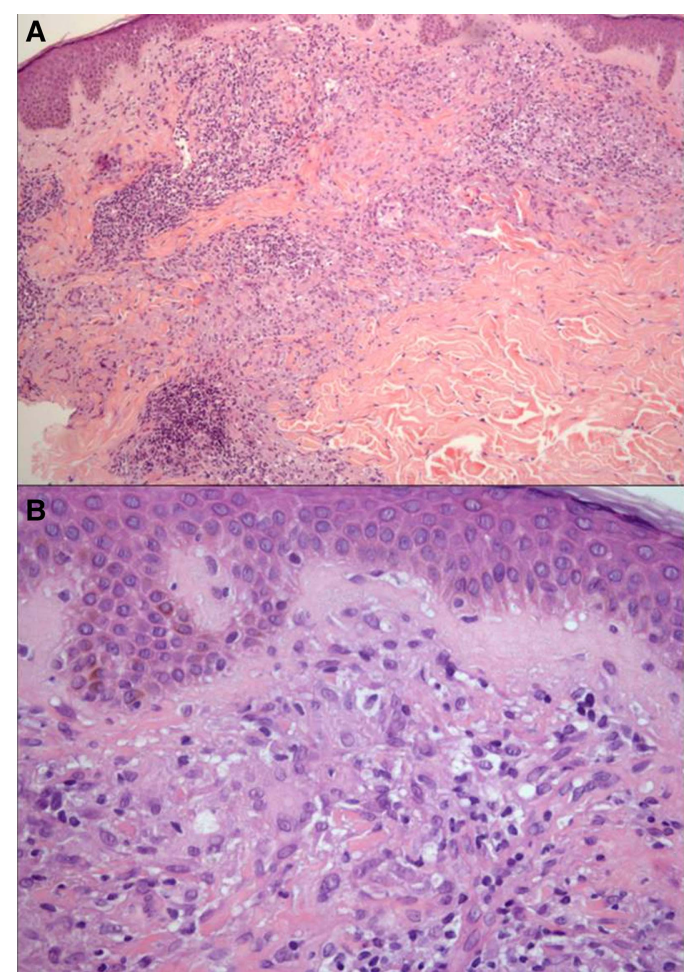

Figure 3 Histopathological examination $(H \& E(A) \times 10$ and $(B) \times 40$ ): lymphohistiocytic infiltrate with histiocytes and multinucleated giant cells in a palisade pattern in the papillary and reticular dermis. Some foci of granulomatous reaction surrounding foci of altered collagen can be observed. 
observed. ${ }^{2}$ Nearly 40 cases of association with neoplasia are reported in published studies, but in only eight cases could a true paraneoplastic nature be proven. Features suggesting association with malignancy are atypical presentation, advanced age, pain and pruritus. ${ }^{3}$ In our patient, a true paraneoplastic course was difficult to establish because the patient died a couple of months later.

Therapeutic options for sporadic granuloma annulare include topical and intralesional corticosteroids, CO2 Laser, PUVA, cryotherapy, niacinamide, infliximab, cyclosporine, antimalarics, pentoxifylline, dapsone and topical calcineurin inhibitors. In the cases where a neoplasm is found, treatment of the cancer should be the aim in the treatment of the granuloma annulare.

\section{Learning points}

- Disseminated granuloma annulare can be associated with hepatocellular carcinoma.

- Atypical granuloma annulare in elderly patients should alert us to the possibility of an occult neoplasia.
Immunosuppressors should always be balanced against the side effects in the neoplasm outcome. ${ }^{2}$

To the best of our knowledge, this is the first published case of an association between a disseminated granuloma annulare and a hepatocellular carcinoma. Atypical granuloma annulare in uncharacteristic locations in elderly patients should alert us to the possibility of an occult neoplasia.

Contributors TM involved in the conception, design, analysis and interpretation of data, drafting of the manuscript and gave final approval; AMR involved in the acquisition of data, analysis and interpretation of data and gave final approval; JC involved in the critical revision of manuscript and gave final approval.

Competing interests None.

\section{Patient consent Obtained.}

Provenance and peer review Not commissioned; externally peer reviewed.

\section{REFERENCES}

1 Miličić V, Ravić-Nikolić A, Jovović-Dagović B, et al. Generalized granuloma annulare presenting as arcuate dermal erythema. Acta Dermatoven APA 2010;19:25-7.

2 Chiu M, Tang M. Generalized granuloma annulare associated with gastrointestinal stromal tumor: case report and review of clinical features and management. Clin Exp Dermatol 2008;33:469-71.

3 Shimizu S, Chicaco Y, Kikuo T. Atypical generalized granuloma annulare associated with two visceral cancers. J Am Acad Dermatol 2006;54:S236-8.

Copyright 2014 BMJ Publishing Group. All rights reserved. For permission to reuse any of this content visit http://group.bmj.com/group/rights-licensing/permissions.

BMJ Case Report Fellows may re-use this article for personal use and teaching without any further permission.

Become a Fellow of BMJ Case Reports today and you can:

- Submit as many cases as you like

- Enjoy fast sympathetic peer review and rapid publication of accepted articles

- Access all the published articles

- Re-use any of the published material for personal use and teaching without further permission

For information on Institutional Fellowships contact consortiasales@bmjgroup.com

Visit casereports.bmj.com for more articles like this and to become a Fellow 